\title{
Influencia de los parámetros de depósito sobre la adhesión del recubrimiento Ni-Al-Mo por spray térmico
}

MATERIALS ENGINEERING

\section{Influence of deposit parameters on the Ni-Al-Mo adhesion of coatings by thermal spray}

\author{
Carlos M. Moreno-Téllez*, Iván F. Pérez-Rodríguez*, Luis C. Quintero-Sánchez* \\ *Grupo de Investigación y Evaluación de Materiales - GIEM, \\ Universidad Pedagógica y Tecnológica de Colombia. Tunja, Colombia \\ carlosmauricio.moreno@uptc.edu.co_ivfrnd@hotmail.com,luisquintero27@outlook.es
}

(Recibido: Abril 28 de 2015 - Aceptado: Junio 20 de 2015)

\begin{abstract}
Resumen
En el presente artículo fue evaluada la influencia de los parámetros de depósito (flujo, distancia, rugosidad superficial y temperatura) sobre la adherencia de un recubrimiento de aleación Ni-Al-Mo, utilizado cómo capa de anclaje, sobre un sustrato de acero AISI 1020. Los resultados muestran la gran influencia que tiene la temperatura de la llama y la distancia de aplicación sobre la morfología y adhesión del recubrimiento. Los resultados de las pruebas de adhesión muestran que ésta es mayor cuando el polvo se aplica a una distancia de $15 \mathrm{~cm}$ entre la pistola y el sustrato, utilizando una atmósfera carburante cuya temperatura de fusión del polvo es mayor. De igual manera, los parámetros de depósito tienen un efecto directo sobre la porosidad y rugosidad superficial del recubrimiento cuya importancia radica en que ésta aleación servirá como superficie de anclaje de recubrimientos depositados sobre el recubrimiento Ni-Al-Mo. La caracterización química, mecánica y microestructural del recubrimiento fue realizada por SEM, XRF, Microdureza y pruebas de Pull off.
\end{abstract}

Palabras clave: Adherencia, recubrimientos cerámicos, rociado térmico, superficie de anclaje

\begin{abstract}
In this research paper the influence of deposition parameters (flow, distance, surface roughness, and temperature) on the $\mathrm{Ni}-\mathrm{Al}-\mathrm{Mo}$ adhesion of coating was evaluated, using as an anchor- base layer on AISI 1020 steel. The results show that the flame temperature and the spraying distance have a great influence on the morphology and adhesion of the coating. Results of adhesion tests show that this increase when the dust is applied at a distance of $15 \mathrm{~cm}$ between the pistol and the substrate using a fuel atmosphere where the temperature of the fusion powder is greater. Likewise, the deposition parameters have a direct effect on the porosity and surface roughness of the coating which the importance of it is that this alloy will serve as anchoring surface coating on the coating deposited Ni-Al-Mo. The chemical, mechanical and microstructural characterization of the coating was made by SEM, XRF, Microhardness and pull off tests.
\end{abstract}

Keywords: Adhesion, ceramic coatings, surface anchoring, thermal spray. 


\section{Introduction}

On an industrial level it is hard to find a metal that satisfactorily fulfills with all the mechanic and chemical properties simultaneously (attrition resistance, corrosion resistance, high temperature resistance); this is because the nature itself of the piece, such as its chemical composition, thermal treatments and shape (Posada \& Gamboa, 2007). It is for this reason that it is necessary the application of superficial layers over the metallic pieces that grant or improve specific properties. These layers can be applied by thermal spraying, a technique known as metallization process in Colombia, which is simple to apply and has shown excellent results to protect different structures and reduce maintenance costs (Marín, 2008).

The flame spraying is a thermal spray technique consisting of the fusion of metallic, ceramic, composite or polymeric materials, in powdered, wire or sticks, through the blending of oxygen and a fuel which is then projected over a preheated substratum in order to create a coating layer. When the particles collide partially or totally molten, a structure named splat is formed (Gonzalez, 2008) that when is superimposed between these ones and added to the deposit nature, a laminate structure is obtained, in whose boundaries can be generated defects such as pores, fissures, oxides, etc. (Ghabchi, et al., 2014). This process can be used in order to protect metals for different uses (Sá Brito, et al., 2012).

Among the various materials used for the elaboration of coatings, the nickel powders are widely used due its low density and high melting point, besides its good thermal conductivity and oxidation resistance. The nickel layers mixed with aluminum lower the stresses between the substratum and the coating and are used as anchor layers to promote the good adherence between the substratum and the coating which give the properties to the piece (Xanthopoulou, et al., 2014).

The adhesion failures in the coatings applied by Oxyacetylene flame spraying are presented due to the low cohesion of the anchor layers to the substratum or between these ones and the aftercoating. For this reason, it is important studying the parameters of the application of the anchor layers in order to improve the adhesion of the coating with the substratum and between the multilayer coatings.

The applications for this type of coatings are many, from thermal barriers used in gas turbines and materials exposed to high temperatures, to superficial recovering of materials used in tribological applications. (Cano, et al., 2006). For example, the coatings used as thermal barriers can be considered as a complex system in which a ceramic layer is used. However, it is not possible to coat directly a metallic substratum with this ceramic due to the stress created on the interface that would bring fissures and defects to the coating. In order to avoid this problem, an intermedium metallic coating rich in nickel and aluminum is used, which also protects the component against corrosion phenomena such as high temperature oxidation. This intermedium layer increases the adhesion of the ceramic coating by providing a rough surface that mechanically anchors this layer. On the other hand, the coating resistance against the oxidation phenomena is due to the presence of active elements such as the aluminum, which forms layers of oxides $\left(\mathrm{Al}_{2} \mathrm{O}_{3}\right.$ mainly), impeding the entry of oxygen into the structure (GómezGarcía, et al., 2006).

The protection against corrosion processes is also a very useful application of this technique because with the passage of time, the pieces degrade due to the corrosion processes generated by the marine environment. These pieces can be recovered through surface engineering, making use of the coatings deposit (Marcela, et al., 2012). Thermal sprayed coatings are also used to improve the tribological behavior of pieces (Saura, et al., 2008).

The parameters of application of coatings comprise the projection distance, the type of atmosphere, the temperature, the superficial preparation as well as the cleanliness and the preheating of the 
substratum, among others. These variables are the most important within the elaboration process of any type of coating (Pawlowski, 2008), because from these parameters different morphological and mechanic characteristics are achieved. Likewise, anchor coatings are widely used to create an additional thickness in those cases in which the superior layers have a thickness limitation (Morán \& Ramírez, 2010).

\section{Methodology}

In order to determine the deposit parameters of the Ni-Al-Mo alloy, the following stages were made:

\subsection{Characterization of powder coating}

To deposit the coating, a commercial powder with Ni-Al-Mo alloy, named Ultrabond 50000, was used. The characterization of the powder coating was made through scanning electron microscope (SEM) techniques, to observe the morphology of the particles and the grain size in order to deduct its function as anchor layer. In addition, some $\mathrm{x}$-ray fluorescence tests were made to determine the chemical composition of the sample.

\subsection{Preparation of substratum}

Test tubes of 1020 steel with diameter of 2,54 $\mathrm{cm}$ and height of $1,00 \mathrm{~cm}$ were machined. The superficial preparation was made through sandblasting, achieving a roughness RA of $7.769 \mu \mathrm{m}$ within the established range $(>7.62$ $\mu \mathrm{m})$ by the CASTOLIN EUTECTIC powder manufacturer (Ultrabond 50000) with the purpose of creating a surface that allows a good adhesion between the coating and the substratum. This kind of preparation is necessary, otherwise the projected particles cannot achieve a mechanic interlacement, besides of allowing a deposit of the coating free of impurities. (Paredes, et al., 2005).

\subsection{Elaboration of coatings}

For the elaboration of the coatings, a projection of the powder with distances of 18, 15 and 12 $\mathrm{cm}$ was made with fuel and neutral atmospheres according to the CASTOLIN EUTECTIC handbook (Standard procedure for cold spraying with CastoDyn 8000, Coating of shafts with
51000 and 19000 on low and high alloyed Steel, 2008), to obtain the coating layer. Prior the coating deposit, the substratum was preheated to $140^{\circ} \mathrm{C}$, with the purpose of eliminating the humidity and reducing the effect of the thermal shock. This preheating allows to the coating a better adhesion to the substratum surface, otherwise the particles reach warm to the substratum and this being cold absorbs the energy necessary to equilibrate the temperature, causing the drop cools and does not adhere properly (Paredes, et al., 2005).

The device used was the CastoDyn DS $8000^{\mathrm{TM}}$ pistol with the SSM 10 nozzle, special for the application of the Ultrabond 50000. When the coating application was finished, the test tubes were measured and weighed, in order to estimate the deposited weight and the height or thickness of the achieved coating layer.

\subsection{Metallographic preparation and characterization}

The metallographic preparation was made according to the ASTM E1920 - 03 ASTM standard (2008). The test tubes were cut off according to the coating application, i.e., making pressure from the coating to the base of the test tube to avoid outbursts. In addition, alcohol was used as lubricant to avoid the oxidation of the test tube.

After cutting the test tubes, proceeded to embed them within a resin to allow the polishing and greatly decrease the outbursts of the coating in order to be watched under the microscope; an acrylic resin was used for this. The test tubes were polished with sandpaper of 220, 240, 500, 600, $1000,1200,2000$ and a cloth with alumina to achieve a mirror shine.

The polished test tubes were observed through optical microscopy (OM) and scanning electron microscope (SEM), to analyze the morphology of the deposited coating and deduce what application parameters allow the proper morphology and thickness, regarding to the anchor layers (Pawlowski, 2008a). 


\subsection{Adhesion tests}

To determine the adhesion of the achieved coatings, a test was made according to the VDI 3198, VDI standard (1991), which initially involves applying a load over the coating and according to a pattern of failure, can be qualitatively deduced if the adhesion is a reason for rejection or acceptance.

To obtain a quantitative value of the coating adhesion, a Pull Off test was made according to the ASTM D4541-09E1, ASTM standard (2008), using an industrial epoxy resin combined with a polyamide catalyst, forming a high viscosity adhesive film.

\section{Results y discussion}

\subsection{Ultrabond 50000 powder characterization 3.1.1 Scanning electron microscope and $X$-ray fluorescence}

Figure 1 shows the shape of the powder particles to project, where some particles of irregular shape and size can be seen, which carries to a rough structure when the particles are being melted and projected over the substratum, ideal as anchor layer.

The results of the $\mathrm{x}$-ray fluorescence test show contents of iron, nickel, chromium and molybdenum, and the $\mathrm{Ni}$ is the predominant element, as shown on Table 1. Figure 2 shows the ionization energy of the Ultrabond 50000 components, observing that the highest energy is that of the alpha nickel which is found approximately to $7.6 \mathrm{KeV}$.

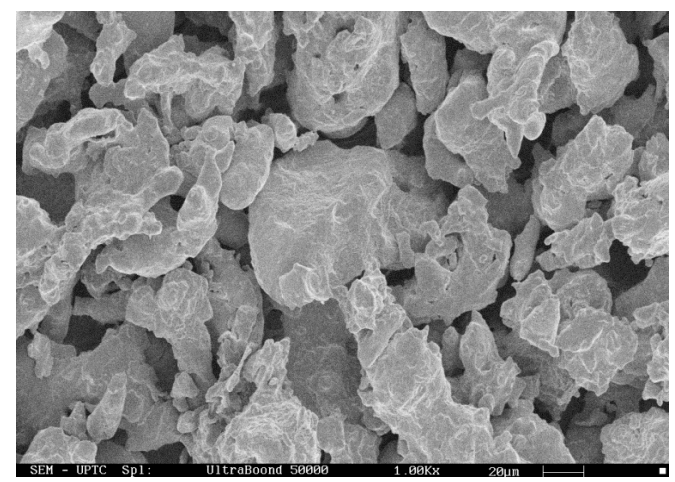

Figure 1. Scanning Electron Microscope to the Ultrabond 50000 coating powder at $1000 x$.
Table 1. Weight composition of an Ultrabond 5000 sample

\begin{tabular}{cc}
\hline Compound & Concentration (\%) \\
\hline $\mathrm{Ni}$ & 92.94 \\
$\mathrm{Mo}$ & 6.2 \\
$\mathrm{Fe}$ & 0.44
\end{tabular}

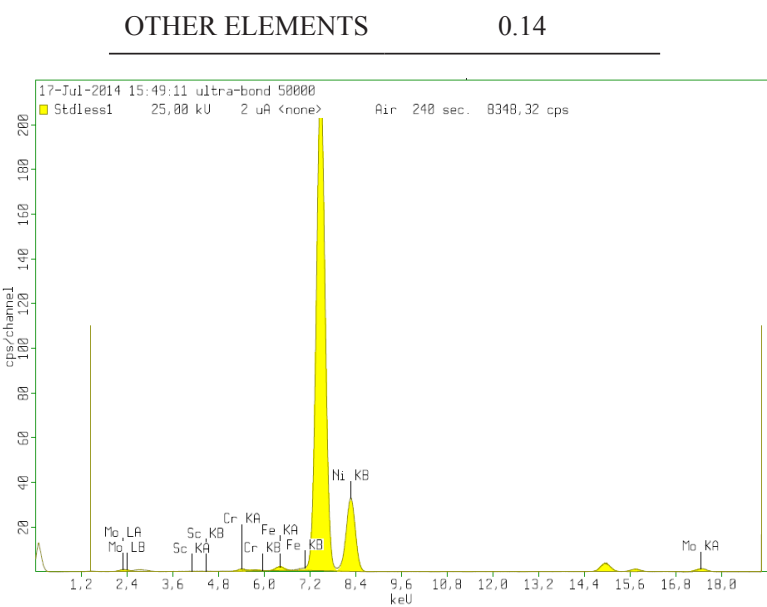

Figure 2. X-ray fluorescence to an Ultrabond 50000 sample

\subsubsection{Elaboration of the coatings}

At the powder application, two types of flame were used (fuel and neutral), at distances of 12 , 15 and $18 \mathrm{~cm}$ from different test tubes for each projection. The thickness of the coating was obtained from many turns, getting a thickness of layer by turn of $25 \mu \mathrm{m}$ approximately; getting a total layer between $100 \mu \mathrm{m}$ and $160 \mu \mathrm{m}$. Tables 2 and 3 show the mean values estimated from the amount of deposited powder, just like the height of the coating layer. The thickness of the layer is between 100 and $160 \mu \mathrm{m}$, being the height (flamesubstratum base) of $15 \mathrm{~cm}$ with fuel flame, the best condition to achieve a thicker layer in the same number of turns, likewise for the neutral flame at $12 \mathrm{~cm}$.

For a single coating layer could be obtained layers with very low porosity, this due to the distribution of the particles over the substratum surface which are in touch with its roughness. From the second layer onward, the porosity increases because of the mechanic effect of the particles of the incoming layers when impacting against the first one (Torres, et al., 2013) 
Table 2. Fuel flame average relation (thickness-weight).

\begin{tabular}{ccc}
\hline & \multicolumn{2}{c}{ FUEL FLAME } \\
PROJECTION & THICKNESS $(\boldsymbol{\mu m})$ & $\begin{array}{c}\text { DEPOSIT WEIGHT } \\
\text { (g) }\end{array}$ \\
\hline 12 & 106,16 & 0,191 \\
15 & 160,6 & 0,313 \\
18 & 110,16 & 0,19 \\
\hline
\end{tabular}

Table 3. Neutral flame average relation (thickness-weight)

\begin{tabular}{ccc}
\hline \multicolumn{3}{c}{ NEUTRAL FLAME } \\
PROJECTION & $\begin{array}{c}\text { THICKNESS } \\
(\boldsymbol{\mu m})\end{array}$ & $\begin{array}{c}\text { DEPOSIT WEIGHT } \\
(\mathbf{g})\end{array}$ \\
HEIGHT $(\mathbf{c m})$ & 110,5 & 0,195 \\
12 & 103 & 0,24 \\
15 & 101,2 & 0,132 \\
\hline
\end{tabular}

\subsection{Coating characterization}

\subsubsection{Coating surface roughness}

Surface roughness measurement was made with MarSurf PS1 surface roughness meter with a path length of $5.60 \mathrm{~mm}$, taking 5 measures per test tube and measuring 3 test tubes for each projection, obtaining the mean of the average roughness shown on Table 4, observing that the greater roughness obtained is achieved through fuel flame and $15 \mathrm{~cm}$ projection distance, which can be attributed to an ideal combination between the distance and the temperature of the flame that allows a proper melting of the powder particles, this in relation to the speed at which the particles are projected. The aluminum content and the rusting with this element can change the coating roughness surface, i.e. its high melting point can project the substratum as semi-molten particles and form irregular layers, which can also lead to fractures of the coating by irregular particles formed with aluminum compounds (Grewal, et al., 2013).

Table 4. Average of surface roughness measurements of the coated test tubes in the 6 projections.

\begin{tabular}{cc}
\hline $\begin{array}{c}\text { PROJECTION } \\
\text { DISTANCE }(\mathbf{c m})\end{array}$ & $\begin{array}{c}\text { ROUGHNESS AVERAGE } \\
\text { Ra }(\boldsymbol{\mu m})\end{array}$ \\
\hline $18 \mathrm{~N}$ & 11,907 \\
$15 \mathrm{~N}$ & 14 \\
$12 \mathrm{~N}$ & 13,39 \\
$18 \mathrm{C}$ & 14,43 \\
$15 \mathrm{C}$ & 16,31 \\
$12 \mathrm{C}$ & 14,36 \\
\multicolumn{2}{c}{$*$ N: Neutral flame } \\
\multicolumn{2}{c}{ C: Fuel flame } \\
\hline
\end{tabular}

\subsubsection{Scanning electron microscope}

Figure 3 shows the morphology of each one of the obtained coatings at different distances in order to make a comparison of the structural characteristics and set the differences between the projections according to the process conditions.

In images of $18 \mathrm{~cm}$ can be observed that with the fuel flame can be obtained a thicker layer than with the neutral flame. Both images have semimolten particles, cracking, and high porosity. Coating outbursts are observed in the image with neutral flame. Nevertheless, part of them are due to the cut or sanding processes.

The porosity occurs mainly by the melting point of the powder, because if the flame does not reach the sufficient temperature to melt the particles, these remain unmelted or semi-molten, which reduces the spray fluidity, causing difficulty in the formation of splats and these are accumulated in a heterogeneous way (Ferrer, et al., 2013).

The images of the projection at a $15 \mathrm{~cm}$ distance, show a dense coating and with more agglomerated and well melted particles, using a fuel atmosphere; this may be right, while for the neutral atmosphere, although it shows a good layer density, is observed the presence of pores and semi-molten particles, besides a cracking between the splats. The thickness achieved at this distance is favorable when the superior layers have thickness limitation, i.e., the anchor coatings can be used to create an extra dimension.

The images of the projections made at a $12 \mathrm{~cm}$ distance, show a great difference between both atmospheres, because for the neutral flame the disunion between splats and porosity is observed in much of the coating layer, besides of horizontal cracks or disunion between the splats, this due to the elevated projection temperature, because for shorter distances there is more heating (Restrepo, et al., 2012); whereas for the fuel flame, the layer is very homogeneous with well melted particles and scarce disunion between these ones.. 
With long paths or long distances, the particles melted by the flame begin to lose heat because these pass through a colder flame area, which absorbs part of the energy that the particles had acquired and therefore, when these collide with the substratum don't have the necessary fluidity to achieve a good packing and with that, a more compact structure (Pérez, et al., 2013).

Regarding to the fuel flame, the EDS results indicate that this type of atmosphere avoids the oxidation of the coating, as observed in Figure 4. This result confirms a TGA-DSC preliminary measure of the precursor powder in which the powder oxidation is observed from $600^{\circ} \mathrm{C}$, reason why in this research the oxidant flame was not used; see figure 5 .

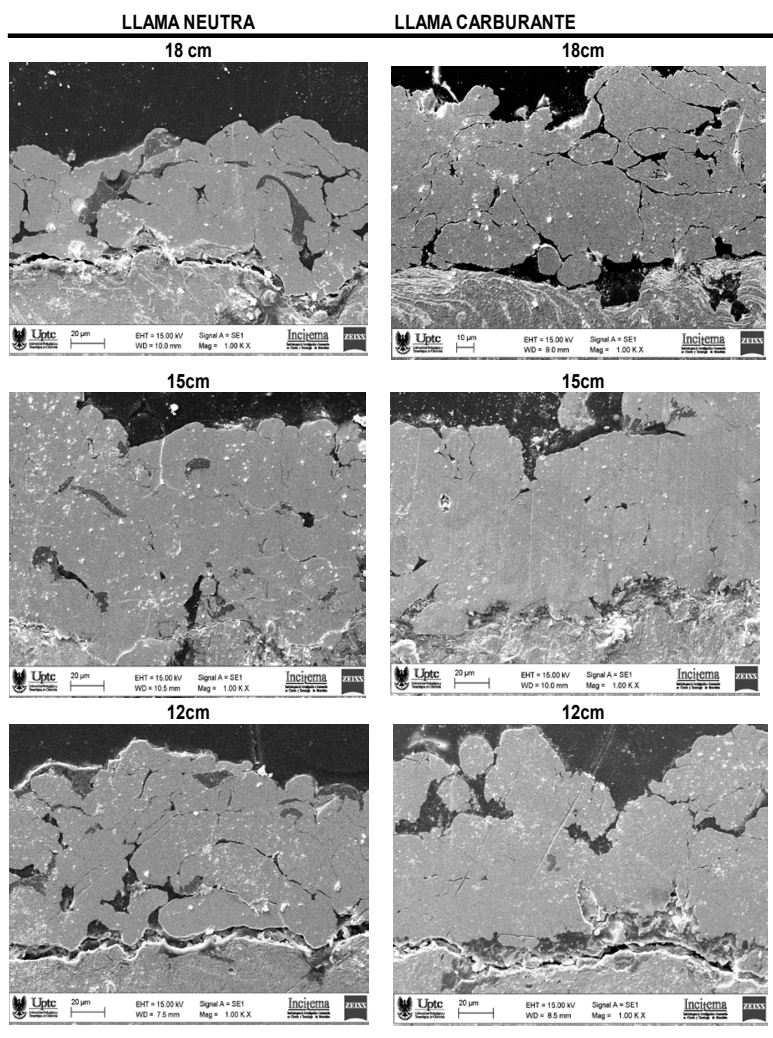

Figure 3. Relation of the coating morphology to the same distances and different types of flame.
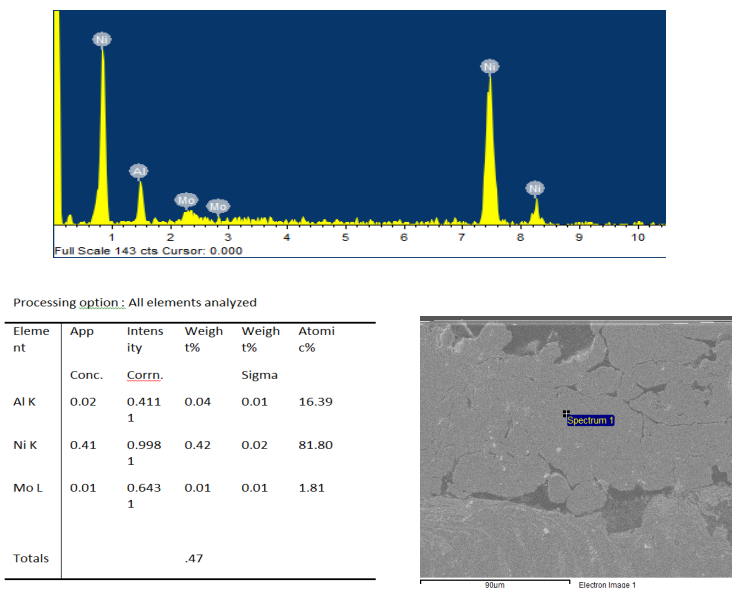

Figure 4. EDS corresponding to the coating applied with fuel flame.

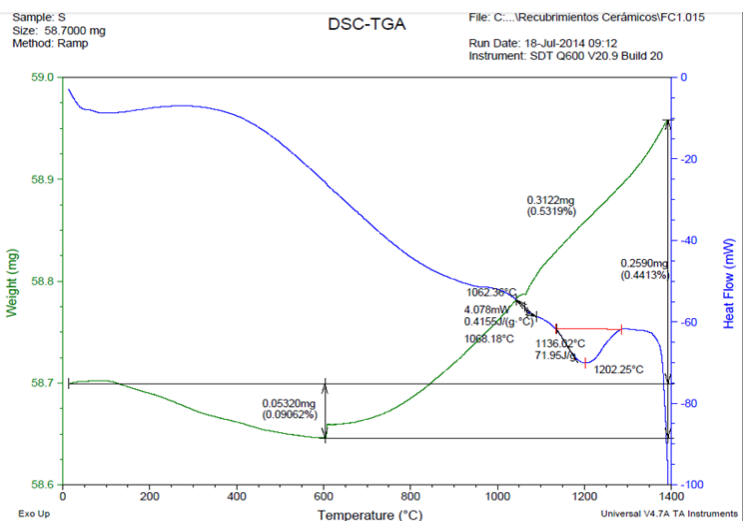

Figure 5. TGA-DSC curve corresponding to the precursor powder.

\subsubsection{Coating adhesion tests}

\subsubsection{Indentation technique}

This technique was made under the VDI 3198, VDI standard (1991a), in order to obtain a qualitative value of the coating adhesion to substratum, from an indentation on the coating for later observe its mark to the microscope, obtaining delamination patterns and in other cases of micro cracks of the coatings, as shown on Figure 6. For the delamination case, it is said that the adhesion is poor and for micro cracks, the adhesion is good. This technique allows understanding the application system in relation with the mechanic 
integrity of the coating, because the influence of parameters as the layer thickness or the substratum roughness can be observed before being coated and the residual tensions that can be observed too (Marot, et al., 2006).

Figure 7 shows micro cracks into the mark, i.e., the defects do not spread towards the shore. In addition, there is no presence of delamination in the mark's environment, which allows to conclude that the adhesion for both coatings is good, as shown in figure 6 .

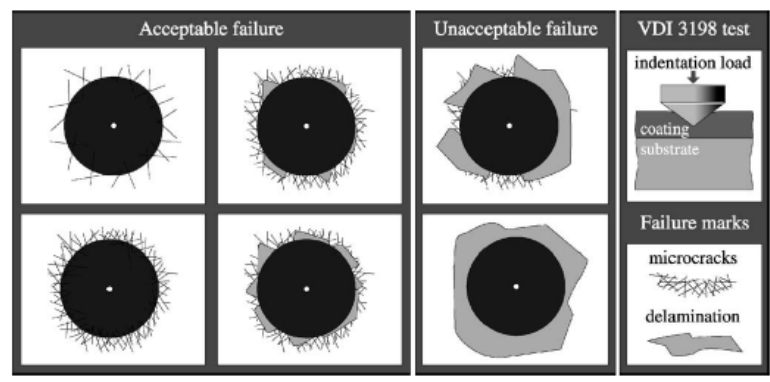

Figure 6. Types of failure in coatings, VDI 3198 standard.

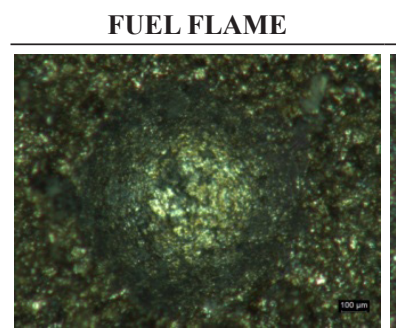

$12 \mathrm{~cm}$

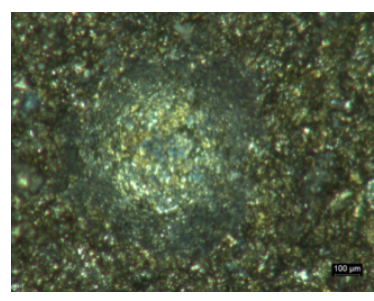

$15 \mathrm{~cm}$

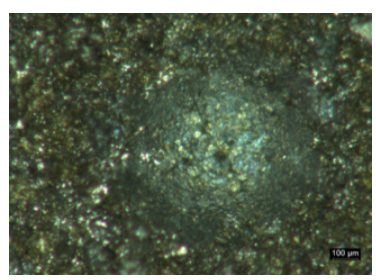

$18 \mathrm{~cm}$

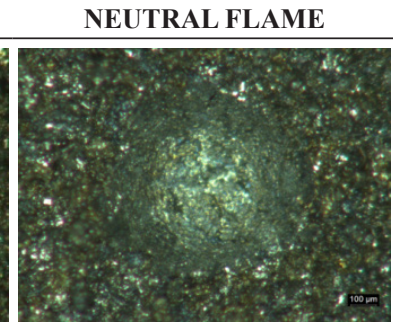

$12 \mathrm{~cm}$

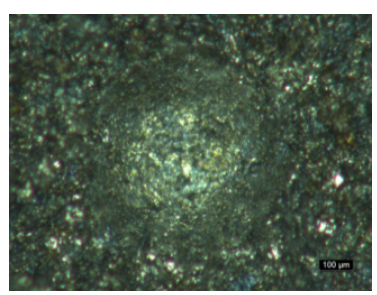

$15 \mathrm{~cm}$

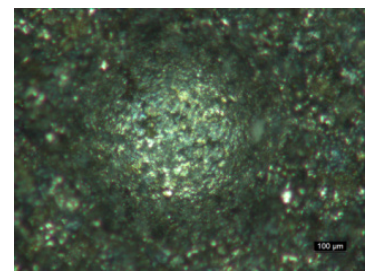

Figure 7. Indentation marks made to the test tubes of each projection.

\subsubsection{Pull off technique}

This technique was made under the ASTM D4541-09E1 ASTM standard (2008a), in order to obtain a qualitative value of the coating adhesion to the substratum.

The test tubes were failed, obtaining the following values:

As it is observed in the Table 5, the adhesion values are higher for the fuel flame, this can be attributed to that this type of atmosphere reaches an approximate temperature of $3200^{\circ} \mathrm{C}$, causing a higher energy than the neutral flame (approx. $2500^{\circ} \mathrm{C}$ ). Thus, the powder melting is performed best and also its deposition, because the distance allows to keep the velocity of the particles and its ejection with high energy and velocity, besides of the radius of application that decreases with the projection distance and allows directing the particles, avoiding the cold drops that cause poor adhesion (Paredes, et al., 2005).

Table 5. Average adhesion values obtained for each projection.

\begin{tabular}{ccc}
\hline $\begin{array}{c}\text { DISTANCE } \\
(\mathbf{c m})\end{array}$ & $\begin{array}{c}\text { FUEL FLAME } \\
\text { ADHESION (psi) }\end{array}$ & $\begin{array}{c}\text { NEUTRAL FLAME } \\
\text { ADHESION (psi) }\end{array}$ \\
\hline 12 & 2444,6 & 1802,3 \\
15 & 2489 & 1661 \\
18 & 2230 & 2111,3 \\
\hline
\end{tabular}

\section{Conclusions}

The adhesion of the obtained coatings was determined from the parameters established for thermal projection. It was found that the best adhesion between the coating and the substratum is achieved when the projection distance is $15 \mathrm{~cm}$ with fuel flame, registering a value of 2489 psi.

The morphologic characterization of the coating by scanning electron microscope (SEM) shows that coatings have a higher density when the distance is $15 \mathrm{~cm}$, either with a fuel or a neutral atmosphere. It is clear that the coating achieved with fuel flame has a best morphology, demonstrated by the limited presence of pores and discontinuities between the splats. 
It was found that the higher roughness values of the coatings, both with neutral flame as with the fuel flame, occur at $15 \mathrm{~cm}$ and the values with less roughness in both cases are in distances of 18 $\mathrm{cm}$. The higher roughness values allow a greater cohesion for a posterior coating.

Coatings have an irregular structure that is favorable when creating a layer of high roughness for posterior coatings deposited over the anchor layer.

\section{Bibliographic references}

ASTM (American Society of Testing and Materials) (2008). Standard Guide for Metallographic Preparation of Thermal Sprayed Coatings, West Conshohocken, United States.

ASTM (American Society of Testing and Materials) (2008). Standard Test Method for Adhesion or Cohesion Strength of Thermal Spray Coatings. West Conshohocken, United States.

Cano, C., M.I. Osendi., \& Miranzo, P., (2006). Effect of the type of flame on the microstructure of $\mathrm{CaZrO}_{3}$ combustion flame sprayed coatings. Surface and Coatings Technology 201 (6), 33073313.

CASTOLIN EUTECTIC (2008). Standard procedure for coldspraying with CastoDyn 8000, Coating of shafts with 51000 and 19000 on low and high alloyed Steel. Menomonee Falls.: EutecticCorporation. http://www.castolin.com/.

CASTOLIN EUTECTIC (Ultrabond 50000) (2008). Menomonee Falls.: EutecticCorporation. http://www.tatiscia.com/termorociado-ymetalizacion/rototec/60-ultrabond-50000.html [Accessed October 2, 2014].

Ferrer, M., Moreno, M., Vargas, F., Peña, G., Vera, E., \& Pineda, Y. (2013). Depósito y caracterización de recubrimientos cerámicos de al2o3 sobre acero 1020 por termorrociado. Revista Colombiana de Materiales (5), 317-322.
Ghabchi, A., Sampath, S., Holmberg, K., \& Varis, T. (2014). Damage mechanisms and cracking behavior of thermal sprayed $\mathrm{WC}-\mathrm{CoCr}$ coating under scratch testing. Wear, 313 (1-2), 97-105.

Gómez-García, J., Poza, P., \& Utrilla, V. (2006). Crecimiento y Caracterización de Recubrimientos Cerámicos con Aplicaciones como Barreras Térmicas. Sociedad Española de Cerámica y

Vidrio, 45 (2), 70-74.

Gonzales, A. (2008). Estudio de la influencia de las propiedades fisicas y mecánicas en el comportamiento tribológico de recubrimientos duros para herramientas de corte y procesamiento de polietileno. Tesis de maetria en ingeniería, Facultad de Ingeniería, Universidad de Antioquia. Medellin, Colombia.

Grewal, H.S., Singh, H., \& Agrawal, A. (2013). Microstructural and mechanical characterization of thermal sprayed nickel-alumina composite coatings. Surface \& Coatings Technology, 216, 78-92.

Marín, C. (2008). Thermal spray, protección de alto impacto. Metal actual 1 (8), 40-45.

Marot, G, Lesage, J, Démarécaux, Ph, Hadad, M, Siegmann, \& St Staia, M.H. (2006). Interfacial indentation and shear tests to determine the adhesion of thermal spray coatings. Surface \& Coatings Technology 201, 2080-2085

Morán, I, \& Ramírez, D. (2010). Caracterización del proceso de rociado térmico de acero inoxidable sobre aceros de bajo contenido de carbono. Tesis ingeniero mecánico, facultad de ingeniería, universidad nacional autónoma de México. México DF, México.

Paredes, C., Amico, S., \& d'Oliveira, A. (2005). The effect of roughness and pre-heating of the substrate on the morphology of aluminium coatings deposited by thermal spraying. Surface \& Coatings Technology 200, 3049 - 3055. 
Pawlowski, L. (2008). The Science and Engineering of Thermal Spray Coatings, John Wiley \& Sons. Available at: http://books.google. com/books?id=firlir6iX_AC\&pgis=1 [Accessed September 30, 2014].

Pérez, M., Gómez, I., Castrillón, D., Hernández, J., Galvis, F., \& López, M. (2013). Estudio de la estructura de recubrimientos de silicio depositados mediante proyección térmica por llama oxiacetilénica. Revista colombiana de materiales (5), 145-151.

Restrepo, E., Vargas, F., López, M., Cardona, R., \& Duarte, G. (2012). Elaboración de recubrimientos cerámicos mediante proyección térmica por combustión a partir de residuos sólidos industriales. Revista materia, 17 (14). 1176-1185

Sá Brito, V.R.S., Bastos, I.N. \& Costa, H.R.M. (2012). Corrosion resistance and characterization of metallic coatings deposited by thermal spray on carbon steel. Materials \& Design 41, 282-288.
Saura, J., Habib, K., Ferrer, M., Cervera, I., Giménez, E., \& Cabedo, L. (2008). Propiedades mécanicas y tribólogicas de recubrimientos alumina / titania proyectados por oxifuel (spray llama). Boletin de la sociedad española de cerámica y Vidrio 47 (1), 7-12.

Torres, B, Campo, M, Lieblich, M, \& Rams, J. (2013). Oxy-acetylene flame thermal sprayed coatings of aluminium matrix composites reinforced with MoSi2 intermetallic particles. Surface \& Coatings Technology. (236), 274-283.

VDI (Verein Deutscher Ingenieure Normen) (1991). Indentation Test Evaluation of a Reliable Qualitative Control for Layered Compounds. Verlag, (Dusseldorf), Alemania.

Xanthopoulou G., Marinou, A., Vekinis, G., Lekatou, A., \& Vardavoulias, M. (2014). Ni-Al and NiO-Al Composite Coatings by CombustionAssisted Flame Spraying. Coatings. Avalaible at: www.mdpi.com/journal/coatings [Accessed april 23, 2015].

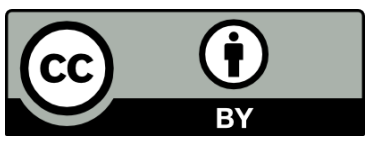

Revista Ingeniería y Competitividad por Universidad del Valle se encuentra bajo una licencia Creative Commons Reconocimiento - Debe reconocer adecuadamente la autoría, proporcionar un enlace a la licencia e indicar si se han realizado cambios. Puede hacerlo de cualquier manera razonable, pero no de una manera que sugiera que tiene el apoyo del licenciador o lo recibe por el uso que hace. 